Vol 3, No 1 (2020): Stadium -Hungarian Journal of Sport Sciences

https://doi.org/10.36439/SHJS/2020/1/5426

\title{
A FIZIKAI AKTIVITÁS ÉS A TESTEDZÉS HATÁSA AZ IMMUNRENDSZER
}

\section{MÛ́KÖDÉSÉRE}

\author{
EFFECTS OF PHYSICAL ACTIVITY AND EXERCISE ON IMMUNE FUNCTIONS
}

Arany Attila Csaba1, Jámbor Ilona², Papp Gábor ${ }^{1,2}$

${ }^{1}$ Debreceni Egyetem, Sporttudományi Koordinációs Intézet, Debrecen

${ }_{2}^{2}$ Debreceni Egyetem, Általános Orvostudományi Kar, Belgyógyászati Intézet, Klinikai Immunológiai Tanszék,

Debrecen

\section{Összefoglaló}

A fizikai aktivitásnak és testmozgásnak kiemelt jelentősége van az egészség fenntartásában és számos megbetegedés kockázatának csökkentésében. A testmozgásnak kifejezett immunomoduláló hatásai vannak, befolyásolja a veleszületett immunrendszer elemeinek, úgymint a neutrofileknek, makrofágoknak, természetes ölősejteknek arányát és funkcióját, mely sejtek a gyulladás kialakításában, fenntartásában, megszüntetésében egyaránt részt vesznek. Az adaptív immunrendszer esetében a Th1/Th2 egyensúly eltolódása történik Th2 irányba, valamint a magas intenzitású edzés emelkedést okoz a regulatórikus T sejtek arányában, szemben a nem megterhelö testmozgás Treg sejtarányt csökkentő hatásával. A testmozgásra adott válaszban a B sejtek érintettségéről nincsenek egyértelmü adatok, ellenben néhány tanulmány az immunglobulin szekréció csökkenéséről számolt be. Saját kutatásaink során a naív és memória B sejtarányok megváltozását figyeltük meg. Edzés hatására az IL-6, egy proinflammatórikus citokin segíti a $T$ sejtek proliferációját, aktiválását, valamint a B sejtek antitesttermelő plazmasejtekké történő differenciálódását is. Az immunológiai változások hátterében a hormonális tényezôk fontos szerepet játszanak. A testmozgás, mind az adrenalin, mind a noradrenalin szekrécióját serkenti, koncentrációjuk a vérben egyenesen arányos a testmozgás idôtartamával. A kimerítô testedzéshez megnövekedett kortizolszint társul, míg kis intenzitású testmozgás jelentősen nem befolyásolja a kortizolszintet. A testmozgás és a fizikai stressz 3-10-szeresére emelheti az endorfinok koncentrációját, a $\beta$-endorfin gátolja a T- és B sejtek aktivitását, így csökkentve az antitesttermelést. A tesztoszteron az IL-4, IL-5, IFN- $\gamma$, illetve Ig-M és Ig-G antitestek csökkentéséhez vezet. Mindezek alapján az enyhe, illetve közepes terheléssel járó fizikai aktivitás hozzájárul az immunreaktivitás fokozódásához, illetve az immunrendszer erôsödő válaszkészségéhez. Ezzel szemben azonban a fokozott intenzitással járó, kimerítő testedzés az immunfunkciók romlásához, az immunológiai védelem károsodásához vezet.

Kulcsszavak: fizikai aktivitás, edzés, immunrendszer 


\section{Abstract}

Physical activity and exercise are especially important in maintaining health and reducing risk of many diseases. Exercise leads to a pronounced immunomodulation by affecting the elements of innate immune system, as well as the ratio and functions of neutrophils, macrophages, natural killer cells, which are involved in the development, maintenance and elimination of inflammation. In the adaptive immune system, Th1 / Th2 balance shift toward Th2, and high-intensity training causes an increase in the proportion of regulatory $T$ cells, as opposed to the effect of non-strenuous exercise on the Treg cell ratio. In response to exercise, there is a lack of data on B cells, but some studies have reported a decrease in immunoglobulin secretion. In our own research we observed changes in naive and memory $B$ cell ratios. Upon exercise, $I L-6$, as proinflammatory cytokine, promotes $T$ cell proliferation, activation, and differentiation of $B$ cells into antibody-producing plasma cells. Hormonal factors play an important role in the background of immunological changes. Exercise stimulates the secretion of both adrenaline and noradrenalin, and their concentration in the blood is directly proportional to the duration of exercise. Endurance exercise is associated with increased cortisol levels, while low intensity exercise does not significantly affect cortisol levels. Exercise and physical stress can increase the concentration of endorphins by 3 to 10 times; $\beta$-endorphin inhibits $T$ and $B$ cell activity, thus reduces antibody production. Testosterone causes a reduction in antibodies to IL-4, IL-5, IFN- $\gamma$, Ig-M and Ig-G. Based on the above, mild to moderate physical activity contributes to the enhancement of immune reactivity and the immune response. On the other hand, strenuous exercise with increased intensity leads to a deterioration of immune function and impaired immunological defense.

Keywords: physical activity, exercise, immune system

\section{BEVEZETÉS}

Az elmúlt évek kutatásai alapján a fizikai inaktivitás globális egészségügyi problémává nőtte ki magát, és összefüggésbe hozható több krónikus betegség kialakulásával, úgymint elhízás, hipertónia, kardiovaszkuláris betegségek, ill. 2-es típusú diabétesz [LAAKSONEN et al., 2002]. A WHO jelentése szerint a fizikai inaktivitás világszerte a halálozások 4. vezető rizikófaktora, s becslések szerint a fizikai inaktivitás a mell- és vastagbélrák 2125\%-ának, a 2-ess típusú cukorbetegség 27\%-ának és az iszkémiás szívbetegségek mintegy 30\%-ának fő oka [WORLD HEALTH ORGANIZATION, 2009]. Mindezek hátterében az áll, hogy a fizikai inaktivitás alacsony intenzitású, krónikus szisztémás gyulladást eredményez, mely bizonyos szövetekben krónikus betegségekhez vezet. Az immunrendszer megváltozott működése malignus daganatok kialakulásához vezethet, míg a proinflammatorikus citokinek zsírszövetből történő felszabadulása inzulin rezisztencia és 2-es tipusú diabetes kifejlődését okozhatja. Jól ismert továbbá, hogy proinflammatorikus citokinek az aktiválódott immunkompetens sejtekkel együtt kulcsszerepet játszanak az atherosclerosis kialakulásában és a kardiovaszkuláris betegségek kifejlődésében [HANDSCHIN et al., 2008]. Mindezek alapján nem meglepő, hogy a rendszeresen végzett fizikai aktivitás, amellett, hogy alapvető fontosságú az energiaegyensúly és a testtömeg-szabályozás szempontjából, javítja a csont és az izomzat 
funkcionális egészségét, csökkenti a magas vérnyomás, a koszorúér-betegség, a stroke, a cukorbetegség, illetve az emlő- és vastagbélrák kialakulásának kockázatát is. A testedzés immunológiai hatásait részleteiben elsőként a kardiovaszkuláris betegségek hátterében álló intravaszkuláris gyulladásos folyamatokkal kapcsolatban vizsgálták. Az atherosclerosis folyamán az oxidált LDL (alacsony sűrűségű lipoprotein) szubendothelialis felhalmozódása számos kemokin és adhéziós molekula expressziójának fokozódásához vezet. Mindez a monociták és T limfociták aktivációját és extravazációját eredményezi, és az általuk termelt proinflammatorikus citokinek az vaszkuláris simaizom sejtek intimában történő migrációjához, az endotheliális dysfunkció fokozódásához és az érfal további strukturális károsodásaihoz vezetnek. Számos randomizált kontrollált vizsgálat eredményei alapján, közepes és magas evidencia szintek mellett megállapították, hogy a rendszeres testmozgás csökkenti a proinflammatórikus citokinek, köztük a tumor nekrózis faktor-alfa (TNF-alfa), interleukin-6 (IL-6) és az interferon-gamma IFN-gamma szérumszintjeit. E tanulmányok heti 3-4 alkalommal végzett 45-60 perces aerob edzések hatásait vizsgálták, átlagosan 3-6 hónapos nyomon követési periódussal krónikus szívbetegségben vagy szívkoszorúér betegségben szenvedő, illetve elhízott betegeken [PALMEFORS et al., 2014]. Kifejezetten immunológiai betegségekben, mint például szisztémás lupus erythematosus, rheumatoid arthritis, szklerózis multiplex vagy irritábilis bél szindróma esetében a testmozgás hatékonyságát és biztonságosságát szintén több vizsgálat is alátámasztotta az utóbbi években [SHARIF et al., 2018]. Az elmúlt évtized kutatásai számos adattal járultak hozzá a különféle sporttevékenységek egészséges szervezetben megfigyelhető immunmoduláló hatásainak jobb megismeréséhez, azonban továbbra is számos kérdés maradt nyitva a témában. Cikkünkben áttekintjük az eltérő intenzitású fizikai aktivitás immunrendszer elemeire és azok funkcióira gyakorolt hatásait, továbbá a releváns változásokat a citokin miliőben és neuroendokrin múködésben az eddigi saját kutatási eredményeink, illetve a vonatkozó szakirodalom tükrében.

\section{A FIZIKAI AKTIVITÁS HATÁSA A VELESZÜLETETT IMMUNITÁSRA}

A neutrofil granulociták a legnagyobb számban előforduló fehérvérsejtek, és a veleszületett immunrendszer nélkülözhetetlen alkotóelemei. E sejttípusok jelennek meg először a gyulladás helyén, kialakítva a gyulladás akut szakaszát. A neutrofilek több olyan funkciókkal rendelkeznek, melyekkel a szervezet patogén ágensekkel szembeni védelmét látják el. Ilyen például a fagocitózis, degranuláció és a reaktív oxidatív burst [SUMMERS et al., 2010]. A testmozgás növeli a perifériás vérben keringő neutrofilek számát, mivel a testmozgás során fokozódik a katecholamin és a kortizol termelés, melyek másodlagosan a neutrofilek erekből és a csontvelőből történő kiáramlását okozzák [PYNE, 1994]. Érdekes módon, 24 órával az aerob edzés után a neutrofilek kemotaktikus aktivitásának csökkenését figyelték meg, mely azonban nem befolyásolta azok baktériumölő aktivitását vagy szuperoxid anion termelését [WOLACH, et al., 2000]. A testmozgás intenzitása azonban jelentősen befolyásolja a neutrofil funkciót. Míg a mérsékelt testmozgás növeli a 
kemotaxis, a fagocitózis és az oxidatív burst intenzitását, addig az extrém, erőteljes testmozgás csökkenti a fagocitózist és az oxidatív burst aktivitást, azonban a kemotaxist és a degranulációt nem befolyásolja [ORTEGA et al., 1993; SMITH J et al., 1992].

A makrofágok a mononukleáris fagocita rendszer fő alkotóelemei, és fontos szerepet játszanak az antigének bemutatásában, így az adaptív immunrendszer aktiválásában. A makrofágok tehát kulcsszerepet játszanak a gyulladás kialakulásában, fenntartásában és a későbbi csökkentésében [FUJIWARA - KOBAYASHI, 2005]. Aerob edzés hatására csökken a toll-like receptor (TLR) expressziója a makrofágokon, nehezítve az antigének bemutatását a T-limfociták számára [GLEESON M, MCFARLIN B, FLYNN M. EXERCISE AND TOLL-LIKE RECEPTORS. EXERC IMMUNOL REV 2006;12(1):34-53.]. Ezenkívül az aerob testmozgás serkenti a makrofágok baktériumölő képességét, ezáltal növelve a proinflammatórikus citokinek széles spektrumának (pl. IFN-gamma, TNF-alfa stb.) termelését és szekrécióját [KIZAKI et al., 2008].

A természetes ölő (natural killer - NK) sejtek a veleszületett immunrendszer effektor limfocitái, amelyek természetes citotoxikus hatással bírnak a vírusokkal fertőzött sejtekkel, illetve a tumorsejtekkel szemben, függetlenül a fő hisztokompatibilitási komplex (MHC) jelenlététől. Az NK sejteknek két fő típusa van: CD56 dimCD16 ${ }^{+}$NK sejtek, amelyek a perifériás keringésben aktívak és általában a sejtek által közvetített citotoxikus hatással bírnak, illetve a CD56 ${ }^{\text {bright }}$ CD16- NK sejtek, amelyek bizonyos citokinek termelése által segítik elő az immunválaszt, mint például a TNF-alfa, IFN-gamma vagy IL-10 [COOPERMA et al., 2001].

A testmozgás intenzitása és időtartama az NK sejteket érintő változások irányát és mértékét is befolyásolja. A könnyü, illetve közepes intenzitású, nem megterhelő testmozgás hatására mind a CD56 bright CD16- NK, mind pedig a CD56 ${ }^{\text {dim }}{ }^{-} D 16^{+} \mathrm{NK}$ sejtek száma emelkedik, és citotoxikus aktivitásuk (NKCA) növekszik. Az ismétlődő, fokozott mértékű edzés már csupán a CD56 brightCD16-NK sejtek aktivitását növeli, míg a nagyon intenzív testmozgás NK-sejtek arányának csökkenéséhez, illetve az NKCA romlásához vezet. Feltételezések szerint, ezt a csökkent NK aktivitást a monocitákból felszabaduló fokozott mennyiségú prosztaglandin E2 okozza, mely citokin hozzájárul az immunválasz csillapításához [PEDERSEN - ULLUM, 1994].

\section{A FIZIKAI AKTIVITÁS HATÁSA AZ ADAPTÍV IMMUNRENDSZERRE}

A testmozgás hatása az adaptív immunrendszerre szintén sokrétú. Fizikai aktivitás során a limfociták aránya emelkedést mutat, mely fokozatosan visszacsökken a kiindulási értékre, sőt intenzív terhelés után még a kiindulási szint alá is mehet. Az edzést követő limfocita szint csökkenését részben az apoptózis fokozódásával magyarázhatjuk [NAVALTA et al, 2007]. A limfocitákban lévő glutation koncentrációjának a csökkenése, valamint a megnövekedett DNS-fragmentáció és a kaszpáz fehérje szintjének növekedése a testmozgás hatására ugyanis fokozott oxidatív stresszt indukál, mely felerősíti az apoptotikus folyamatokat. A $\mathrm{T}$ limfociták az adaptív immunrendszer fontos részét képezik, két fő csoportjuk a CD4+ $\mathrm{T}$-helper sejtek és a CD8 ${ }^{+}$citotoxikus T-sejtek. A CD4+ $\mathrm{T}$ - 
sejtek további alcsoportjai a Th1 és Th2 sejtek. A Th1 sejtek IFN-gamma-t és IL-2-t termelnek, míg a Th2-sejtek IL-4, IL-5, IL-6-ot szekretálnak [PAPP et al., 2017]. Az időben elhúzódó, kimerítő testmozgás szignifikáns csökkenést eredményez a Th1 sejtek arányában, ellenben a Th2 sejtekben nem, ezáltal a Th1/Th2 egyensúly eltolódását váltja ki a Th2 sejtek irányába [KAKANIS et al., 2014]. Ezt a szelektivitást a hormonrendszerben bekövetkezett változások magyarázhatják, elsősorban a kortizol szintek növekedése. A kortizol gátolja az antigén prezentáló sejtek (APC) IL-12 termelését, amely a Th1 sejtek közismert stimulátora [ELENKOV ET AL., 1999]. Emellett az adrenalin, amely szintén emelkedik edzés közben, két különböző mechanizmussal, nevezetesen az APC gátlásával és a T-sejt receptor közvetlen blokkolásával gátolja a Th1 sejteket [PEDERSEN HOFFMAN-GOETZ, 2000]. Saját kutatásaink során is leírtuk a Th2 irányú sejtprofil változást [BERKI et al., 2019]. Fontos továbbá aláhúzni, hogy a Th1/Th2 arány befolyásolja az egyének ellenálló képességét a fertőzésekkel, allergiával és az autoimmun megbetegedésekkel szemben.

A regulatórikus $\mathrm{T}$ (Treg) sejtek a $\mathrm{T}$ helper sejtek egy olyan csoportja, mely kulcsszerepet játszik az immunfolyamatok szabályozásában és a gyulladásos folyamatok mérsékelésében. E sejttípusra jellemző a CD4 és a CD25 molekulák felszíni expressziója, illetve a FoxP3 transzkripciós faktor expressziója, mely a Treg sejtek éréséhez fontos [SZODORAY et al., 2009]. A rendszeres, magas intenzitású edzés hatására több tanulmány is szignifikáns emelkedést írt le a Treg-sejtek arányában és számában [SCHWINDT et al., 2007; WILSON et al., 2009; WEINHOLD et al., 2016]. Emellett a TGF- $\beta$ szintje is emelkedett, mely egy anti-inflammatórikus hatású citokin, és hozzájárul a Treg sejtek képződéséhez és immunszuppresszív múködéséhez [WEINHOLD ET AL., 2016]. Fontos azonban hangsúlyozni, hogy Treg sejtarányok emelkedését olimpikon úszók, illetve profi jégkorongozók fokozott terhelését követően mutatták ki a kutatók. Saját kutatásaink során mi azonban a CD4+CD127-CD25 bright Treg sejtek arányának jelentős csökkenését írtuk le, melyet nem élsportoló egészséges személyek rendszeresen végzett, közepes intenzitású funkcionális edzésprogramjának hatására mértünk [PAPP et al., 2019a]. Mindez azt tükrözi, hogy a Treg sejtek esetében is nagyban függ a kiváltott válasz a sportolás intenzitásától.

Érdekes módon, a testmozgásra adott válaszban a korábbi vizsgálatok nem számoltak be a B-sejtek érintettségéről, ennek ellenére számos kutatás során írták le az immunoglobulin szekréció csökkenés intenzív fizikai terhelést követően [TOMASI et al., 1982; THARP et al., 1990]. Az immunglobulin szekréció gátlásának mechanizmusát még nem sikerült egyértelmúen tisztázni, azonban a hátterében állhat, hogy a testmozgás alatt a monociták széleskörű populációjából nagy mennyiségben felszabaduló IL-2 érzékenyíti a B-sejteket és fogékonnyá teszi azokat a prosztaglandinokkal történő gátlásra [TVEDE et al., 1989]. Vizsgálataink alapján azonban a rendszeresen végzett sporttevékenységek szignifikáns hatással vannak a B sejt alpopulációk arányára. Méréseink szerint közepes intenzitású terhelés az IgD+ naív B sejtek aránya csökken, míg a CD27+ izotípusváltáson átesett memória B sejtek aránya emelkedik, melynek hatására effektívebb és gyorsabb immunválasz alakulhat ki az esetleges fertőzések során [PAPP et al., 2019b]. 


\section{A FIZIKAI AKTIVITÁS ÉS A CITOKIN SZINTEK}

A korábbi tanulmányok alapján a fizikai aktivitás akár a 100-szorosára is növelheti az IL6 szintet a vérben, a normál értékhez képest [NORTHOFF - BERG, 1991; BRUUNSGAARD et al., 1997]. Proinflammatórikus citokinként az IL-6 elősegíti a T-sejtek proliferációját és aktiválását, valamint a B-sejtek antitest-termelő plazmasejtekké történő differenciálódását. A fizikai aktivitást követően a vázizomban az IL-6 mRNS transzkripciós aktivitása is növekszik [MUÑOZ-CÁNOVES et al., 2013]. Ez az emelkedés izomkárosodás jele nélkül fordul elő, mivel nem előzi meg TNF-alfa termelődés, ami általában gyulladásos állapotokban fordul elő [NIEMAN et al., 1998]. Antiinflammatórikus myokinként múködve az IL-6 indukálja az IL-1 receptor antagonista (IL1RA) és az IL-10 felszabadulását. Az IL-1RA az IL-1 $\beta$ természetes inhibitora, mely utóbbi egy proinflammatórikus citokin. Az IL-10 egy jól ismert, hatékony gyulladásgátló citokin, amely gátolja a T-sejteket és csökkenti a gyulladásos folyamatokat [DE VRIES JE, 1995].

\section{A FIZIKAI AKTIVITÁS ÉS HORMONSZINTEK}

Fizikai stressz esetén a szervezet neuroendokrin rendszere fontos immunmoduláló funkciókat lát el. A testmozgás mind az adrenalin, mind a noradrenalin szekrécióját serkenti a mellékveséből, és a szimpatikus idegvégződésekből egyaránt. Ezen hormonok koncentrációja a vérben egyenesen arányos a testmozgás időtartamával és exponenciálisan nő annak intenzitásával [KJAER - DELA, 1996]. Az adaptív immunrendszer T és B limfocitái rendelkeznek $\beta$-adrenoreceptorokkal. A $\beta$-receptorok aktiválódása egy sejten belüli többlépcsős folyamatot indít be, amely ciklikus adenozinmonofoszfát (c-AMP) előállítását, majd adenilát-cikláz aktiválását eredményezi. Ez a jelátvitel idézi elő a c-AMP útvonalon a T-sejtek általi citokinek termelését [WEHBI TASKÉN, 2016]. A kortizol plazmaszintje is a testedzés időtartamának függvényében változik. A hosszan tartó, kimerítő testedzéshez megnövekedett kortizolszint társul, míg egy rövidebb, kis intenzitású testmozgás érdemben nem befolyásolja a kortizolszintet [HILL et al., 2008]. A megnövekedett kortikoszteroid szint limfocitopéniát eredményez, mely másodlagosan vezet a korábban említett, edzéshez társult apoptózishoz, melynek mértéke 4 órával a testedzés után a legnagyobb [RABIN et al., 1996]. A testmozgás és a fizikai stressz 3-10-szeresére emelheti az endorfinok koncentrációját [MAISEL et al., 1990]. A $\beta$-endorfin gátolja a T és B sejtek aktivitását, csökkentve az antitesttermelést, ezzel szemben az NK-sejtek aktivitását viszont fokozza [MORGAN et al., 1990; MATHEWS et al., 1983]. A nemi hormonok szintjei is szorosan összefüggnek a testedzéssel. Kimutatták, hogy a tesztoszteron egyaránt befolyásolja az adaptív immunrendszer sejtes és humorális immunválaszát, mivel az IL-4, IL-5, IFN-gamma, Ig-M és Ig-G antitestek csökkentését okozza [ARANEO et al., 1991; KANDA et al., 1996]. 


\section{MEGBESZÉLÉS}

A fizikai aktivitás immunmoduláló hatása nagyban függ az adott mozgásformától, annak intenzitásától és időtartamától. A szakirodalmi adatok alapján a rendszeresen végzett közepes intenzitású edzés javítja az immunológiai múködéseket, ezáltal csökkentheti a fertőzésekre való hajlamot. Ezzel szemben a magasabb intenzitású testmozgás fokozza az anti-inflammatórikus választ, és csökkenti az immunrendszer aktivitását, ezáltal segíthet a krónikus gyulladásos betegséggel társult kórképek kezelésében, és azok megelőzésében. A megerőltető és hosszan tartó edzés azonban olyan mértékben ronthat az immunológiai funkciókon, ami már a szervezet immunvédelmének jelentős károsodásához is vezethet. A fizikai aktivitás és sportolás immunrendszerre, s a vele kapcsolatos neuroendokrin rendszerre gyakorolt hatásának irodalma folyamatosan bővül. Azonban az eredmények összehasonlításánál, értékelésénél és interpretációjánál jelentős problémát okoz az, hogy az egyes tanulmányokban egymással nem összehasonlítható edzésformák és programok szerepelnek és a laboratóriumi vizsgálatoknál a mintavételi időpontok eltérnek egymástól, illetve különböző sejtek eltérő jelölési módszerekkel vannak meghatározva. A fizikai aktivitást követő egyes immunológiai változások, mint pl. a Treg sejtek arányának emelkedése/csökkenése nem tisztázott, hogy milyen mechanizmussal történik, ezért további vizsgálatokra van szükség a testmozgás különböző formáinak az immunrendszerrel és a vele összefüggő hormonális rendszerrel való kapcsolatának tisztázására.

\section{Köszönetnyilvánítás}

A kutatás a GINOP-2.3.2-15-2016-00062 azonosító számú, „Életminőség fejlesztése KeletMagyarországon: Táplálkozás-, teljesítménybiológiai és biotechnológiai experimentális kutatások és eszközfejlesztések a humán megbetegedések megelőzésére és kezelésére" című projekt keretében történt.

Papp Gábor munkája a Magyar Tudományos Akadémia Bolyai János Kutatási Ösztöndíjának, illetve az Innovációs és Technológiai Minisztérium Bolyai+ Felsőoktatási Fiatal Oktatói és Kutatói Ösztöndíjának (Új Nemzeti Kiválóság Program - ÚNKP-19-4-DE35) támogatásával valósult meg.

Arany Attila Csaba az EFOP-3.6.1-16-2016-00022 azonosító számú „Debrecen Venture Catapult Program” keretében megvalósuló Hallgató Tehetséggondozó Program ösztöndíjában részesült. 


\section{IRODALOMJEGYZÉK}

Araneo B.A., Dowell T., Diegel M., \& Daynes R.A. (1991). Dihydrotestosterone exerts a depressive influence on the production of interleukin-4 (IL-4), IL-5, and gammainterferon, but not IL-2 by activated murine T cells. Blood, 78, 688-699.

Berki A.R., Arany A.C., Jámbor I., Szabó K., Mile M., Makra G., Csiki Z., Balogh L., \& Papp G. (2019). Investigation on the Immunological Effects of Regular Physical Activity. Stadium - Hung J Sport Sci, 2, 1-15.

Bruunsgaard H., Galbo H., Halkjaer-Kristensen J., Johansen T.L, MacLean D.A, \& Pedersen B.K. (1997). Exercise-induced increase in serum interleukin-6 in humans is related to muscle damage. J Physiol, 499(Pt 3), 833-841.

Cooper M.A, Fehniger T.A., \& Caligiuri M.A. (2001). The biology of human natural killercell subsets. Trends Immunol, 22, 633-640.

de Vries J.E. (1995). Immunosuppressive and anti-inflammatory properties of interleukin 10. Ann Med, 27, 537-541.

Elenkov I.J., Chrousos G.P. (1999). Stress hormones, Th1/Th2 patterns, pro/antiinflammatory cytokines and susceptibility to disease. Trends Endocrinol Metab, 10, 359368.

Fujiwara N., Kobayashi K. (2005). Macrophages in inflammation. Curr Drug Targets Inflamm Allergy, 4, 281-286.

Handschin C., Spiegelman B.M. (2008). The role of exercise and PGC1alpha in inflammation and chronic disease. Nature, 454, 463-469.

Hill E.E., Zack E., Battaglini C., Viru M., Viru A., \& Hackney A.C. (2008). Exercise and circulating cortisol levels: the intensity threshold effect. J Endocrinol Investig, 31, 587591.

Kakanis M.W., Peake J, Brenu EW, Simmonds M, Gray B, \& Marshall-Gradisnik S.M. (2014). T helper cell cytokine profiles after endurance exercise. J Interferon Cytokine Res, 34, 699706.

Kanda N, Tsuchida T, \& Tamaki K. (1996). Testosterone inhibits immunoglobulin production by human peripheral blood mononuclear cells. Clin Exp Immunol, 106, 410415.

Kizaki T, Takemasa T, Sakurai T, Izawa T, Hanawa T, Kamiya S, et al. (2008). Adaptation of macrophages to exercise training improves innate immunity. Biochem Biophys Res Commun, 372, 152-156.

Kjaer M., Dela F. (1996). Endocrine responses to exercise. In: Hoffman-Goetz L, editor. Exercise and Immune Function, 231-256.

Laaksonen D.E., Lakka H.M., Salonen J.T., Niskanen L.K., Rauramaa R., \& Lakka T.A. (2002). Low levels of leisure-time physical activity and cardiorespiratory fitness predict development of the metabolic syndrome. Diabetes Care, 25, 1612-1618. 
Maisel A.S., Harris T, Rearden C.A., \& Michel M.C. (1990). Beta-adrenergic receptors in lymphocyte subsets after exercise. Alterations in normal individuals and patients with congestive heart failure. Circulation, 82, 2003-2010.

Mathews P.M., Froelich C, Sibbitt W., \& Bankhurst A. (1983). Enhancement of natural cytotoxicity by beta-endorphin. J Immunol, 130, 1658-1562.

Morgan E.L., McClurg M.R, \& Janda J.A. (1990). Suppression of human B lymphocyte activation by ß-endorphin. J Neuroimmunol, 28, 209-217.

Muñoz-Cánoves P., Scheele C., Pedersen B.K., \& Serrano A.L. (2013). Interleukin-6 myokine signaling in skeletal muscle: a double-edged sword? FEBS J, 280, 4131-4148.

Navalta J., Sedlock D., \& Park K. S. (2007). Effect of exercise intensity on exercise-induced lymphocyte apoptosis. Int J Sports Med, 28, 539-542.

Nieman DC, Nehlsen-Cannarella S.L., Fagoaga O.R., Henson D.A.., Utter A, Davis J.M., et al. (1998). Influence of mode and carbohydrate on the cytokine response to heavy exertion. Med Sci Sports Exerc, 30, 671-678.

Northoff H., Berg A. (1991). Immunologic mediators as parameters of the reaction to strenuous exercise. J Sports Med, 12(Suppl. 1), S9-15.

Ortega E, Collazos M.E., Maynar M, Barriga C, \& De la Fuente M. (1993). Stimulation of the phagocytic function of neutrophils in sedentary men after acute moderate exercise. Eur J Appl Physiol Occup Physiol, 66, 60-64.

Palmefors H, DuttaRoy S., Rundqvist B., \& Börjesson M. (2014). The effect of physical activity or exercise on key biomarkers in atherosclerosis - a systematic review. Atherosclerosis, 235, 150-161.

Papp G., Boros P., Nakken B., Szodoray P., \& Zeher M. (2017). Regulatory immune cells and functions in autoimmunity and transplantation immunology. Autoimmun Rev, 16, 435444.

Papp G., Szabó K., Jámbor I., Mile M., Csiki Z., \& Balogh L. (2019a). Investigation on the immunological effects of regular physical exercise. Allergy, 74, 421.

Papp G., Szabo K., Jambor I., Mile M., Csiki Z., \& Balogh L. (2019b). Immunomodulatory effects of regular physical exercise in older age. Eur J Immunol, 49, 50.

Pedersen B.K., Ullum H. (1994). NK cell response to physical activity: possible mechanisms of action. Med Sci Sports Exerc, 26, 140-146.

Pedersen B.K., Hoffman-Goetz L. (2000). Exercise and the immune system: regulation, integration, and adaptation. Physiol Rev, 80, 1055.

Pyne D.B. (1994). Regulation of neutrophil function during exercise. Sports Med, 17, 245258.

Rabin B.S., Moyna M.N., Kusnecov A, Zhou D, \& Shurin M.R. (1996). Neuroendocrine effects of immunity. In: Hoffman-Goetz L, editor. Exercise and Immune Function, 21-38. 
Schwindt C.D., Zaldivar F, Wilson L, Leu S.Y., Wang-Rodriguez J, Mills P.J., \& Cooper D.M. (2007). Do circulating leucocytes and lymphocyte subtypes increase in response to brief exercis in children with and without asthma? Br J Sports Med, 41, 34-40.

Sharif K., Watad A., Bragazzi N.L., Lichtbroun M, Amital H., \& Shoenfeld Y. (2018). Physical activity and autoimmune diseases: Get moving and manage the disease. Autoimmun Rev, $17,53-72$.

Smith J., McKenzie S., Telford R., \& Weidemann M. (1992). Why does moderate exercise enhance, but intense training depress, immunity. In: Husband E, editor. Behavior and Immunity, 155-168.

Summers C., Rankin S.M., Condliffe A.M., Singh N, Peters A.M., \& Chilvers E.R. (2010). Neutrophil kinetics in health and disease. Trends Immunol, 31, 318-324.

Szodoray P., Papp G., Horvath I.F., Barath S., Sipka S., Nakken B., \& Zeher M. (2009). Cells with regulatory function of the innate and adaptive immune system in primary Sjögren's syndrome. Clin Exp Immunol, 157, 343-349.

Tharp G.D., Barnes M.W. (1990). Reduction of saliva immunoglobulin levels by swim training. Eur J Appl Physiol Occup Physiol, 60, 61-64.

Tomasi T.B., Trudeau F.B., Czerwinski D., \& Erredge S. (1982). Immune parameters in athletes before and after strenuous exercise. J Clin Immunol, 2, 173-178.

Tvede N., Heilmann C., Halkjaer-Kristensen J., \& Pedersen B. (1989). Mechanisms of B lymphocyte suppression induced by acute physical exercise. J Clin Lab Immunol, 30, 169173.

Wehbi V.L., \& Taskén K. (2016). Molecular mechanisms for cAMP-mediated immunoregulation in $\mathrm{T}$ cells - role of anchored protein kinase a signaling units. Front Immunol, 7, 222.

Weinhold M., Shimabukuro-Vornhagen A., Franke A., Theurich S., Wahl P., Hallek M., et al. (2016). Physical exercise modulates the homeostasis of human regulatory T cells. J Allergy Clin Immunol, 137, 1607-1610.

Wilson L.D., Zaldivar F.P., Schwindt C.D., Wang-Rodriguez J., \& Cooper D.M. (2009). Circulating Tregulatory cells, exercise and the elite adolescent swimmer. Pediatr Exerc Sci, 21, 305-317.

Wolach B., Falk B., Gavrieli R., Kodesh E., \& Eliakim A. (2000). Neutrophil function response to aerobic and anaerobic exercise in female judoka and untrained subjects. $\mathrm{Br} J$ Sports Med, 34, 23-28.

World Health Organization (2009). Global health risks: Mortality and burden of disease attributable to selected major risks. Geneva, Switzerland 